\title{
Production response of lambing ewes receiving supplementary feed while grazing wheat stubble
}

\author{
T.S. Brand ${ }^{1}$, B. Aucamp ${ }^{1}$ and A. Durand ${ }^{2}$ \\ ${ }^{1}$ Elsenburg Agricultural Centre, P Bag X1, Elsenburg, 7607, ${ }^{2}$ Langgewens Experimental Farm, P Bag X2, Moorreesburg, \\ 7310
}

\section{Introduction}

In the past, several experiments were conducted at the Langgewens Experimental Farm in the Swartland area of the Western Cape to evaluate different types of supplementary feed for producing ewes while grazing low quality crop residues during the dry summer and early autumn months (Brand, et al, 2000). These include molasses, urea, fishmeal and combination licks; molasses, urea and combination licks; barley, urea, sweet lupins and combination licks as well as other locally produced feed sources such as winter grains lupins (Brand et al 1992a; Brand et al 1992b; Brand et al 1997a; Brand et al 1997b). This information was used to formulate supplementary feed mixtures. In this experiment the effect of supplementary feeding on the production responses of ewes grazing stubble lands was measured over a two-year period.

\section{Material and Methods}

Sixteen flocks of sheep (14-25 ewes per flock) which grazed wheat stubble continuously for 124-150 days per year for two years were used as experimental units. The ewes grazed at a stocking density of 5 ewes/ha. Eight flocks received a supplementary lick (Table 1) during the lost 6 weeks of pregnancy ( $200 \mathrm{~g} / \mathrm{ewe} / \mathrm{d})$ and the first 6 weeks of lactation $(200 \mathrm{~g}-300 \mathrm{~g} / \mathrm{ewe} / \mathrm{d})$, while the other eight flocks received no supplementary feed. Differences between groups were detected by analysis of variance.

Table 1 Composition of supplement fed to ewes grazing wheat stubble.

\begin{tabular}{ll}
\hline \multicolumn{1}{c}{ Ingredient } & Amount (kg/ton) \\
\hline Barley meal & $570 \mathrm{~kg}$ \\
Cottonseed oilcake & $221 \mathrm{~kg}$ \\
Urea & $37 \mathrm{~kg}$ \\
Slaked lime & $15.5 \mathrm{~kg}$ \\
Molasses powder & $15 \mathrm{~kg}$ \\
Flour of Sulfur & $1.5 \mathrm{~kg}$ \\
Salt & $140 \mathrm{~kg}$ \\
& \\
Total & $1000 \mathrm{~kg}$ \\
\hline
\end{tabular}




\section{Results and Discussion}

Short paper and poster abstracts: $38^{\text {th }}$ Congress of the South African Society of Animal Science

Table 2 The effect of supplementary feeding on SA Mutton Merino ewes.

\begin{tabular}{|c|c|c|c|c|}
\hline \multirow[t]{2}{*}{ Measurement } & \multicolumn{2}{|c|}{ Treatment } & \multirow{2}{*}{$\begin{array}{l}\text { Standard } \\
\text { Error }\end{array}$} & \multirow[t]{2}{*}{ Significance $(\mathrm{P})$} \\
\hline & $\begin{array}{c}\text { No supplementary } \\
\text { feed }\end{array}$ & $\begin{array}{c}\text { Supplementary } \\
\text { feed }\end{array}$ & & \\
\hline \multicolumn{5}{|l|}{ Ewes: } \\
\hline Number of flocks & 8 & 8 & - & - \\
\hline Starting weight, $\mathrm{kg}$ & 56.7 & 56.7 & 0.7 & NS \\
\hline End weight, $\mathrm{kg}$ & 53.9 & 59.4 & 0.9 & 0.002 \\
\hline Live weight change, $\mathrm{kg}$ & -18.7 & -14.0 & 1.2 & 0.02 \\
\hline Lambing percentage, $\%$ & 146.3 & 155.3 & 7.7 & NS \\
\hline Weaning percentage, $\%$ & 102.3 & 120.1 & 5.9 & 0.05 \\
\hline Lamb production/ewe, $\mathrm{kg}^{+}$ & 19.9 & 25.6 & 1.7 & 0.09 \\
\hline Wool production/ewe, $\mathrm{kg}$ & 3.04 & 3.24 & 0.1 & NS \\
\hline \multicolumn{5}{|l|}{ Lambs: } \\
\hline Birth weight, kg & 4.16 & 4.39 & 0.2 & NS \\
\hline Docking weight, kg & 6.77 & 8.07 & 0.4 & 0.04 \\
\hline Weaning weight, kg & 32.8 & 33.2 & 0.5 & NS \\
\hline Survival rate, $\%$ & 70.1 & 77.7 & 4.4 & NS \\
\hline
\end{tabular}

Clear differences in the end weights $(5.5 \mathrm{~kg})$, live weight change during the last 6 weeks of pregnancy and the first 6 weeks of lactation (feeding period; $4.7 \mathrm{~kg}$ ), weaning percentage $(18 \%)$ and mass weaned lamb per ewe $(5.1 \mathrm{~kg})$ occurred in favor of ewes grazing the supplemented stubble land. The supplementary feed also increase the weight of lambs at docking but had no significant effect on birth weight, weaning weight or lamb survival. It however seems that the higher lamb survival, in absolute terms, leads to the significantly higher weaning percentage in favor of the supplemented group. In a calculation based on food consumed $(18.3 \mathrm{~kg}$ lick at R0.80/kg $=\mathrm{R} 14.64 / \mathrm{ewe}$ ) and potential meat production (dressing percentage of $45 \%)(12.3 \mathrm{~kg}$ meat at $\mathrm{R} 12.00 / \mathrm{kg}=$ R27.60/ewe) an economic advantage of R12.96 per ewe was found in favour of supplementary feeding.

\section{References}

Brand, T.S. et al.,1992a. SA. J. Anim. Sci. 22, 58.

Brand, T.S. et al., 1992b. SA. J. Anim. Sci. 22, 170.

Brand, T.S.et al., 1997a. Austr J Exp Agric 37, 1.

Brand, T.S.et al., 1997b. Small Rum Res 26, 93.

Brand, T.S.et al., 2000. Small Rum Res 35, 29. 